\title{
A STUDY OF THE WHITE HEART-ROT OF LOCUST, CAUSED BY TRAMETES ROBINIOPHILA
}

\author{
C. H. Kauffman and H. M. Kerber
}

(Received for publication February 24, 1922)

\section{INTRODUCTION}

The actual distribution of the active mycelium during the process of decay in living trunks of various timber trees, and the process of such decay in the production of "heart-rots," is still poorly understood. If one examines the literature on the subject, it soon becomes evident, however, that sufficient data are at hand to conclude that the relation of any specific heart-rotting fungus to a specific tree is either specific itself or belongs to one of a group of type reactions. We are far enough in the study to realize that generalizations on these reactions are impossible.

In the study of a rot caused by Trametes robiniophila Murr., we paid little attention to the number of trees affected or to the question of the value of locust timber. The inroads of the locust borer, and, in the more southern distribution of the locust tree, the abundant heart-rot due to Fomes rimosus, both loom as so much more important enemies to be controlled before the locust tree can find its rightful place in lumber economy, that it seems futile to attempt to make an important case of the rot in question.

Our attention was therefore directed to an analysis of one case: the macroscopic and microscopic characteristics of the rot; its mode of advance; the distribution of the mycelium in the various portions of the affected trunk; and its effect on the various elements of the wood.

That the white heart-rot of Robinia Pseudo-Acacia L. is quite frequent in southern Michigan there is no doubt. Its presence is not to be reckoned by the number of sporophores observed, since it appears to fruit sparsely, and when it does the sporophore rarely lasts more than one season or is soon attacked by insect enemies or disintegrated by wind and weather. The black-locust tree is found scattered along some of the Ann Arbor streets, and not a few show symptoms of heart-rot. From year to year sporophores may be noticed on some of them, and the tree selected for study had had a large yellowish sporophore on it the year before, and at the time of cutting had produced another from an old frost crack that had almost healed over; in addition, signs of several old scars left by former sporophores were still distinguishable on the trunk. Although the tree was suffering from both borer attacks and the heart-rot, as shown by a number of large dead branches and the straggly condition of the crown, 
[Vol. 9.

its leaves were green and vigorous, and in general stili making considerable growth. The internal condition of the trunk and dead branches would soon, however, have made it a prey to wind and storm. This tree was about 35 years old and had reached a height of $3 \mathrm{I}$ feet with a 24 -inch base.

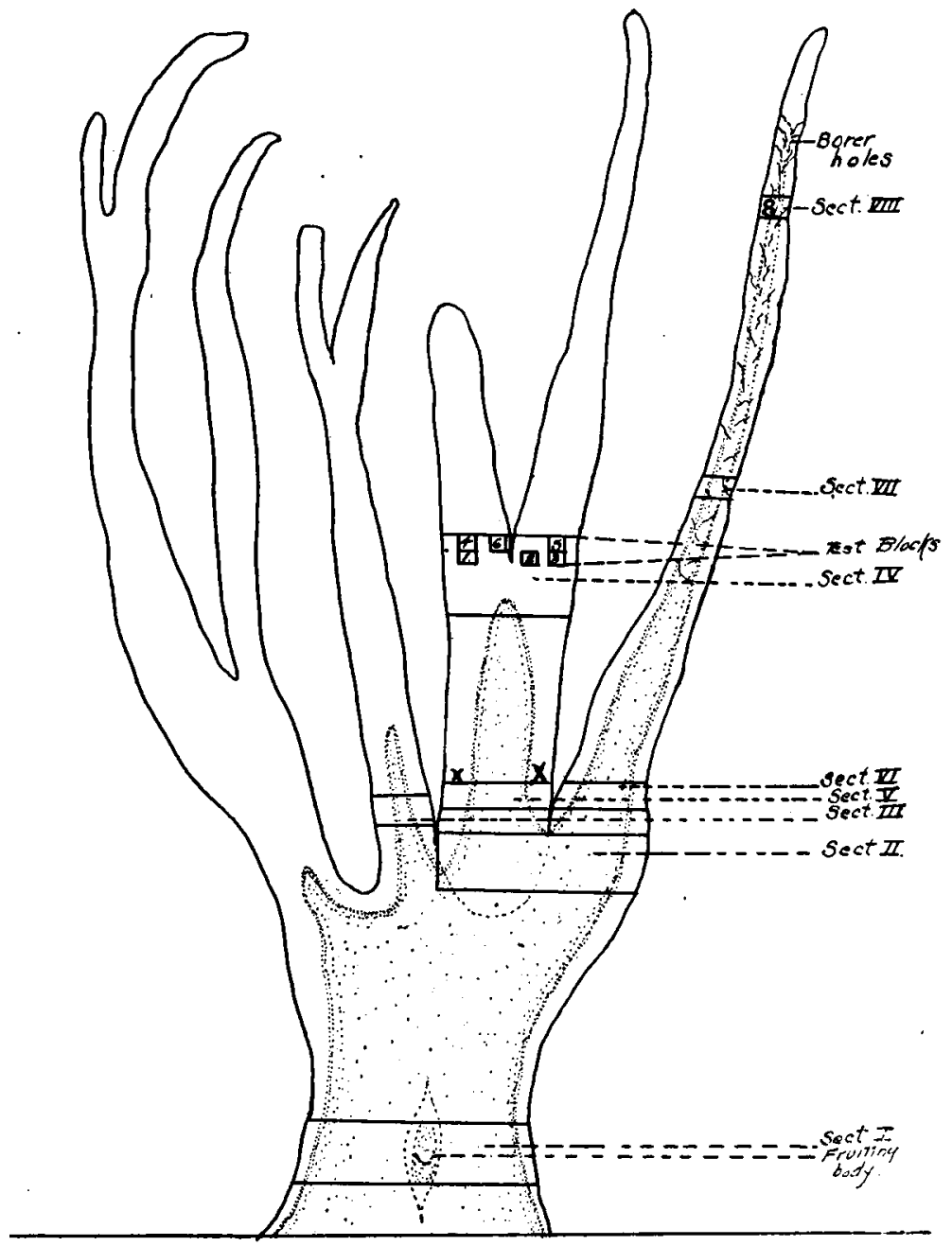

FIG. I. Diagram showing diseased area of the black locust.

(Infection by Trametes robiniophila Murr.)

After cutting and sectioning, it was soon evident that the fungus had entered by an old borer hole through one of the large upper branches now dead. As shown in the diagram of the tree (fig. 1 ), the rot, starting in this branch about 15 feet above ground, moved downwards through the branch and trunk. Another main branch near by had in the meantime become affected upwards from the trunk only a short distance. Both 
these branches were perforated with borer channels horizontally and vertically, and when present, either in apparently sound wood or in slightly rotten wood, these channels would be found to contain mycelium. The spread of the rot from these channels is shown in figure 2 .

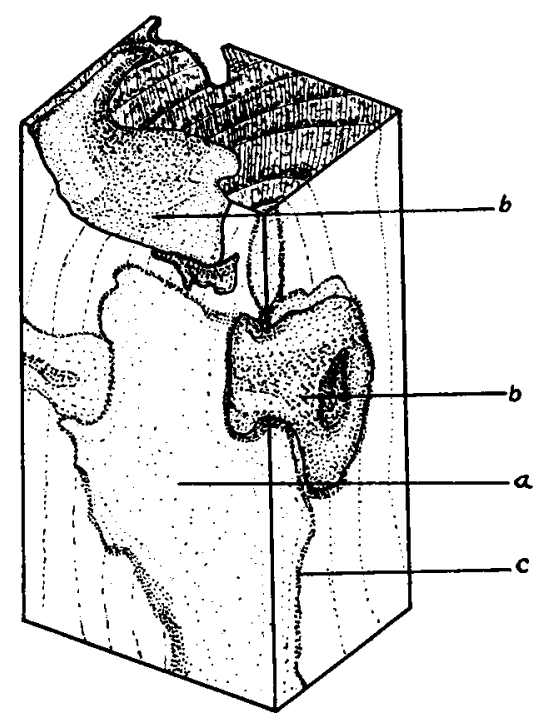

FIG. 2. From a piece of diseased black locust, cut from the region of the sound wood of section VI. It is clearly shown that the points of infection throughout the diseased tree were the borer channels. $a$, area of decay; $b$, borer channels; $c$, dark border zone of rot.

Old borer channels in badly decayed wood were indistinct and were recognized by pellets of dead mycelium.

\section{DESCRIPTION OF THE ROT}

The diseased area of rot of Trametes robiniophila may be divided into three stages:

I. Black Border Zone. The apparently sound wood of the tree is sharply differentiated from the rotten area by a very fine, distinct, brownishblack zone, having a width that varies between $\mathrm{I} / 4$ and $\mathrm{I} / 2$ millimeter. This zone is very irregular in outline, but invariably tends to maintain the same color and width.

2. Lesser Decayed Portion. There is a sharp differentiation between the apparently sound and the decayed wood immediately adjoining and outside the black zone. The decayed wood is of a light fawn color to a brownish white except where traversed by borer channels where it assumes a dark brown to reddish appearance. The borer channels are filled with old, dead mycelium. The decayed wood is of a solid texture, but very much softer and lighter in weight than the sound wood. This first stage of rotted wood cuts very easily without breaking. 
3. The Last Stage of Decayed Wood. The color of the most badly decayed wood remains the same as that of the less decayed stuff, but there is a difference in its texture. Instead of the wood being soft and easily cut without breaking, it has now become very dry and friable and is easily crumbled between the fingers. It cannot be cut without breaking. In addition, white streaks appear at frequent intervals in the vertical sections, and upon examination these are found to be pure wood fibers, containing very little lignin. These streaks are present in only the very final decay of the tree. The borer channels are not visible, being choked with old masses of mycelium which closely resemble in color the decayed wood. The contents of these channels have a rubbery consistency and are in the form of pellets. The mass of decay holds together fairly well, but would crumble away in time and thus cause a hollow interior.

The rotted portion of a section taken near the base appeared like a star in outline, or as if some powerful acid had been spilled over the section and had changed the texture of all the wood with which it had come into contact. The dark border ring was not very distinct in this section horizontally, but could be seen very well on the longitudinal portion. At a few points, the fungus became powerful enough to break through the sapwood and cambium in order to form fruiting bodies, and here the decayed wood appears a darker brown, of soft, friable texture.

\section{Microscopic Characteristics of Fungus and Host Tissue}

The tree was cut up and eight sections were selected for study. These are shown in the diagram of the tree (fig. I).

Before much work was done on the actual course of the fungous hyphae in the cells, quite a bit of time was spent in the laboratory in preparing free-hand sections of sound wood, partially decayed wood, and badly decayed wood. These sections were both radial and tangential and were taken from section I (see fig. I). These sections were stained with chloriodide of zinc for cellulose reactions and with phloroglucin and hydrochloric acid for lignin reactions. These tests were later confirmed by the use of eosin and also of congo red, the latter as a cellulose test. The best test for cellulose and lignin, aside from chloriodide of zinc, and phloroglucin and $\mathrm{HCl}$, was that of haematoxylin for cellulose and safranin for lignin. In the case of the haematoxylin, the Heidenhain method was the best. ${ }^{1}$ Finally,

1 The sections were washed in distilled water and then immersed in a 2 percent solution of iron alum. They were left in the iron alum for about five minutes and then washed twice in distilled water, care being taken to get all the free alum out of the sections before transferring them to the haematoxylin. When this had been accomplished, the sections were transferred to a $I / 2$ percent solution of haematoxylin and allowed to remain for a minute or two. They were again washed and then transferred to a $I$ percent solution of safranin, made up of equal parts of alcohol-soluble and water-soluble safranin. The result was a blue for the cellulose and a red for the lignin. The sections can be left for any length of time in the safranin. 
in order to compare the cellulose and lignin tests in a positive way, microtome sections were made of wood from a sound tree from another source, cut in the three planes: cross, radial, and tangential. There was, of course, quite an elaborate technique involved in merely trying to find the differentiation of cellulose and lignin tissue in black locust, but the time was well spent as will be shown later. Permanent slides were attempted for the diseased portion of the wood of the tree studied but without success, because of the damaging influence of the hydrofluoric acid on the already weakened tissues.

All sections were taken from sound wood of section I and from one to two inches in from the sapwood. Sections were radial and tangential ones. These tests were corroborated by permanent mounts of black locust stained with haematoxylin and safranin.

TABLE I. The Result of Staining for Cellulose and Lignin in the Normal Wood

Elements

Cellulose Test

Med. ray cells......... Good cellulose test, deep blue color; not all ray cells showed cellulose test

Tracheids and vessels..... Did not show any cellulose reactions, with the exception of the tyloses in the vessels, which are pure cellulose

Wood parenchyma....... These showed a good cellulose blue reaction, in decided contrast to the vessels which they surround

Wood fibers

These showed both a cellulose and lignin reaction, due to two types of fibers present in locust: mucilaginous fibers which stain blue with haematoxylin, and the ordinary fiber which stains red
Lignin Test

Some ray cells showed good lignin color (True of ray cells in heartwood of black hcust)

Showed a good lignin test, with exception of tyloses

Did not show a lignin test

Showed a good lignin stain for the ordinary wood fiber present in black locust

In testing the decayed portion of section I, sections were taken of (a) the black border zone; $(b)$ the less decayed portion of the wood; and (c) the badly decayed portion of the wood. Radial and tangential sections were made of all these parts. 
TABLE 2a. Black Border Zone of Decay; Results of Testing the Tissues for Cellulose and Lignin. Width of Zone, $\mathrm{I} / 4$ to $\mathrm{I} / 2 \mathrm{~mm}$.

Elements

Cellulose Test

Med. ray cells. Good cellulose test, but does not show through brown area

Tracheids and vessels..... No cellulose test

Wood parenchyma....... Good cellulose test where not hidden by brown substance

Wood fibers........... Cellulose for mucilaginous fibers
Lignin Test

Slight lignin test as observed in sound wood

Good lignin test

No lignin

Good lignin test for ordinary wood fiber

TABLE 2b. Lesser Decay of Wood; Results of Testing the Decayed Tissue for Cellulose and Lignin. Sections made Free-hand from Larger Section I

Elements

Cellulose Test

Med. ray cells. Good blue color for ray cells

Tracheids and vessels.... . Deep blue color in tyloses

Wood parenchyma . Fair bluish stain with haematoxylin

Wood fibers

. Still bluish for mucilaginous fibers
Lignin Test

No lignin remaining in ray cells, and where present very faint

Fair lignin, but not as deep red as that in normal wood

No lignin present

Fair lignin present

TABLE 2c. Badly Decayed Portion of Wool; Results of Testing the Decayel Tissue for Cellulose and Lignin. Sections both Radial and Tangential, Taken from Section I

Elements

Cellulose Test

Med. ray cells.......... Very good blue color

Tracheids and vessels.... Those which are still remaining give a good blue for the tyloses

Wood parenchyma....... Give good reaction for cellulose

Wood fibers........... Color is absent in the ordinary fibers and blue is present in the mucilaginous fibers
Lignin Test

No lignin present

Scarcely perceptible lignin color

No lignin

Give a very faint to colorless reaction with a lignin test

The results thus speak for themselves. The hyphae have the power of dissolving the lignin from the wood by enzymatic action. 


\section{Study of the Elements of the Normal Black Locust}

Black locust normally has very little sapwood, this in most cases being only three to four rings in width. This sapwood is of a whitish to a pale lemon color and is in decided contrast to the golden brown of the heartwood. It is a ring-porous hardwood, that is, there is a distinct variation in the size of the spring line of vessels as compared to those of the summer wood, as seen in cross section. These vessels in the heartwood are filled with tyloses, which fact makes locust one of the choice woods for tight cooperage stock. The tyloses are also supposed to act as a protection against the invasion of disease. The vessels are of the very highest types, having simple endwall pits and spiral vessel markings. The tracheids also have spiral wall thickenings, but these are of the tertiary type. It may be mentioned in this connection that the tertiary thickenings of the spiral walls of the tracheids resemble the hyphae of Trametes robiniophila so closely that no attempt was made to find hyphae in the tracheids.

Wood parenchyma is found only surrounding the vessels in Robinia Pseudo-Acacia. This fact marks the wood as vasicentric wood-one of the highest of the hardwoods. The wood-parenchyma tissues are cellulose and stand out clearly when a haematoxylin stain is used. The cell walls are comparatively thin, and the pits are simple when communicating with the ray cells.

The fibers are of two kinds:

I. Libriform Fibers. These are called mucilaginous fibers in black locust. Jeffrey says (The anatomy of woody plants, pp. 33, 34):

In these elements the inner portion of the wall has become more or less completely modified into a mucilaginous state which causes it to stain strongly with haematoxylin. The presence of fibers of this description is often of value from the hygroscopic quality imparted to the wood, which prevents undue shrinking or swelling. These numerous mucilaginous fibers made the wood particularly valuable for tree-nails in the days of the construction of wooden ships.

2. The second kind of fiber present in black locust is the ordinary wood fiber, with a thick wall composed of lignin. These fibers are the principal source of strength, hardness, and toughness in broad-leaf woods. Their function is principally a mechanical one. In Robinia, they are in rather large, compact masses in the late wood, separated by groups or bands of pores and parenchyma.

The ray cells and wood parenchyma are the only living tissues in the heartwood of the locust, and even these too become lignified after a time. Lignification of the ray cells is common in the early stages of heartwood transformation. The ray cells of locust belong to the diffuse type of ray, for they have more than one layer of ray cells. They are filled with living tissue, mostly containing starch, and give a cellulose reaction with the proper stain. The ray cells are storage cells for food and help in the distribution of water in the horizontal plane of the tree. The ray cells have 
simple pits where they communicate with the wood parenchyma, and semibordered pits where they communicate with the vascular tissues, such as the tracheids and vessels.

\section{Diseased Wood}

Both macerated material and free-hand sections of the different stages of the rot were used. By this means data were obtained as to the exact rôle played by each kind of element in the advancement or retardation of the mycelium in the wood. For maceration, the pieces were placed in a solution containing Io percent nitric acid and ro percent chromic acid in equal proportions. The containers were kept in a warm bath for $2 \frac{1}{4}$ hours, then washed clear of the acid and kept in water with a few drops of chloroform. The free-hand sections were stained with eosin in order to bring out the hyphae when present. The following results were brought out by these studies:

I. Black Border or Transition Zone. Here was noticed a distinct, narrow, dark-brown strip of rot, whose elements were infiltrated for the most part by a brownish substance. This circular strip was varied by small, V-shaped irregularities, the point of the $\mathrm{V}$ taking its origin in the medullary ray and wood-parenchyma cells. These two kinds of elements also contained the darkest infiltrations, especially the ray cells as observed in tangential section. The base of the $\mathrm{V}$-shaped irregularities encompassed the tracheids, vessels, and both kinds of wood fibers. The contents of the last named were much lighter in color, and seemed to indicate greater resistance on the part of these elements to the dissolving action of the hyphae. No hyphae were observed in this zone, but evidence of their former presence was plentiful; the ray cells and wood parenchyma showed the characteristic small, rounded perforations, and some of the pits of the tracheids and vessels were eroded. All kinds of solvents and stains were tried to change the color of the brown deposit, but without success. In general it may be said that little damage seemed to have been caused by the hyphae, for the elements seemed perfectly normal except for the brown and blackish inclusions and the holes made by the hyphae in the walls. This zone, as far as its woody elements are concerned, is in about the same stage of decay as the apparently sound zone beyond it, which is to be discussed later. If hyphae were present, they must have been overlooked because of the optical difficulties in the study of this zone.

This blackish-brown substance has been variously accounted for. Rhoads (1917) gives a summary of the views held by different workers. That it is a phase in a series of chemical changes taking place within the dead cells seems an unavoidable conclusion, since the zone containing these colored inclusions passes outward as the rotten core advances radially. We $d \mathrm{~d}$ not concern ourselves with the question of its origin, whether an infiltration, a gradual change from original protoplasm and other cell 
contents, or a residue from wall surfaces. The forward movement of this zone of dark elements is, however, a significant consideration in interpreting this substance. It may not be out of place to speculate, from our advancing knowledge of colloidal chemistry, that, if it is of protoplasmic origin, colloidal stages might be assumed of which the brown color is a character, to be followed by physico-chemical changes through which, by a change from the colloidal condition into molecular constituents, the color disappears. In such processes time is as much a factor as is the necessary ratio of the ingredients. Von Schrenk's (19I4) findings in Syringa, according to which the brown substance is supposed to be destroyed by the fungus in its later activities, can play no part in our case. As will be shown later, there is no active mycelium behind the black zone to which we can refer this action. Nor can we say that the black zone is formed by the advance guard of the oncoming hyphae, since, as will also appear below, the hyphae are present and active beyond and outside the black zone.

2. Lesser Rot Zone. Inside of the black zone, and by indefinable stages to the very rotten center, we have a zone marked sharply only on its exterior side. Here the decay may be said to be less complete than in the central zone. The hypha-holes through the walls of the elements were much larger and much more numerous than in the black zone. This was particularly true for the ray cells and the wood parenchyma. The cell contents of both ray and wood parenchyma had entirely disappeared. The larger hypha-holes were measured and found to range from three to ten microns in diameter. The other elements were all attacked by the hyphae, the holes being smaller and less numerous. The fibers seemed to be affected least of all. No hyphal threads could be found, although a diligent search was made for them. In a tangential or radial section containing the tracheids it is very easy to mistake the tertiary thickenings of the walls for mycelium, due to the width, color, and direction of these thickenings, and therefore scant attention was paid to the tracheids, the most careful search, however, being made in the wood parenchyma and medullary ray cells. When single macerated cells were teased out and examined, it was found that the holes made by the hyphae were rounded and smooth and much larger than the width of the hyphal threads as found later. This fact may be accounted for by assuming that the fungous enzyms still persisted although the hyphae had disappeared, and hence the diameter of the holes was increasing as solution continued. It was also found that in these isolated cells the hyphae must have entered the cells through the pits, as well as penetrating directly through the wall. The medullary ray cells and wood parenchyma, although badly decayed, did not break up in the same fashion that the vessels and tracheids did. The fibers held together very well. Not a particle of starch or even of living matter could be found in the wood parenchyma or in the ray cells of this portion of the decay.

3. Badly Decayed Areas. In the center of the rotten core the wood was 
so brittle that good free-hand sections could be made only with great difficulty. An attempt to imbed and make microtome sections failed because of the crumbly nature of this material. It was noticed that the size of the hypha-holes had increased, until in places the walls were so thoroughly riddled that they had parted as soon as the middle lamellae were dissolved by the maceration fluid. All the elements were so affected, with the possible exception of the fibers which still held the wood together, supported by the skeleton cell walls of the rays. The tracheids and vessels were merely a broken mass of fragments and recognizable only through their spiral markings, etc. In both the medullary ray cells and the wood parenchyma, it appears that the hyphae merely utilized the starch and other contents of these cells and then worked through from these cells as origins, to the vessels, tracheids, and fibers. The wood parenchyma surrounds the vessels in Robinia, and therefore this would be a particularly good place for the hyphae to work from. This is also true of the ray cells, which are very closely linked up with the other elements.

In macerated portions of this badly rotted area, it was found that the wood parenchyma and the medullary ray cells, although badly riddled, still retained their original outlines and were still easily recognizable, whereas the tracheids and vessels were recognized only through the fragments that had spiral markings. The fibers in most cases were perforated in scattered areas but still held together strongly.

The very end decay showed nothing but the fibers remaining, and these of a distinctly colorless appearance. The wood parenchyma and medullary ray cells were now not very easily recognized. These fibers were very uneven in outline, indicating that most of the wall had been dissolved away. It is these fibers that give the appearance of white mycelial patches in the very end decay, when the decayed material is placed in water for a few days.

4. Apparently Sound Wood outside the Black Zone. Having failed in all our studies to locate mycelium in the rotten portion of the trunk, an examination of the apparently sound wood was undertaken. For this purpose a slab was selected which still had three inches of sound wood outside the black zone, viz., section VII. This was supplemented by section I, with a narrower border of sound wood. Free-hand slices were at first made about two millimeters outside the black zone, and here mycelium was found in abundance. The mycelium was exceedingly fine, from I to I.5 microns in diameter, hyaline, and could easily be confused with edges of walls, etc., except for its characteristic windings and branchings and for the presence of delicate cross walls. Under the eosin stain it assumed a pale greenish color which contrasted sufficiently well with the reddened color of the cell walls to double our assurance. When it occurred in the wood parenchyma as seen in tangential sections, the threads were usually parallel to the long axis of the cell and had branches which penetrated the adjoining 
cells either by way of the pits or directly through the cell wall. In the case of the parenchyma cells of the ray, the main threads of mycelium were found traversing the cells crosswise and sending branches into the cell. These hyphae were much more numerous in the medullary and wood parenchyma cells than in the tracheids, vessels, and fibers.

Other sections were then made from portions about $7 \mathrm{~cm}$. beyond the black zone, and stained with eosin. Here also hyphae were present in relatively large numbers. The character of the mycelium could of course be compared with that in the sapwood immediately surrounding the sporophore of Trametes robiniophila. At first this comparison was disconcerting, since the hyphae ranged larger as one approached the fruiting body, varying from two to nine microns in diameter. Part of this, however, may have belonged to secondary fungi which had found a foothold in the old and crumbling sporophore or at its base on the dead wood. However, as one examined the more characteristic hyphae here, they were found to have a branching system in which end branches were abundant and became progressively more minute, thus corresponding to the size of the hyphae in the apparently sound wood.

From what was found in these studies it became apparent that, although to all appearance the wood beyond the black zone was normal and exactly like good, sound locust wood, in reali ty there was no longer any sound normal wood present in this tree in a radial direction from the rotten core, and, from a cursory examination, this was also the case in a vertical direction from the uppermost rot to at least a distance of two feet.

\section{Supporting Evidence of Decay in the Apparently Sound Wood}

It seemed reasonable to infer from the presence of mycelium, hyphaholes, and some erosion, even if slight, that the apparently sound wood must already be weakened by this preliminary decay. It was therefore decided to make some tests of the compression strength of this wood so as to be able to make an approximate comparison with the strength of known sound locust wood as given in the tables by Newlin and Wilson (l.c.). It is to be understood in advance that the few tests made and the many variables possible in dealing with decayed wood for such tests, can give us no more than a very general idea of the actual difference between such affected wood and sound wood. However, the results were sufficiently contrasting to demand attention.

Two small blocks, about $6-\mathrm{cm}$. cubes, numbered $\mathrm{I} x$ and $2 x$, were cut out of the sound portion of section VI (fig. I), outside the black zone. Six blocks were cut from the upper portion of section IV (fig. I), situated vertically above the farthest point of the black zone, being in a portion where advance rot might be expected. The uppermost blocks were numbered 4,5 , and 6 . The ones from the next adjoining layer below were numbered I, 2, and 3. These blocks were situated from 20 to 30 centi- 
meters above the farthest visible rot, which had scarcely entered the lower side of our section IV. As the wood tested had been in the laboratory for about nine months, it had lost considerable of its water content before

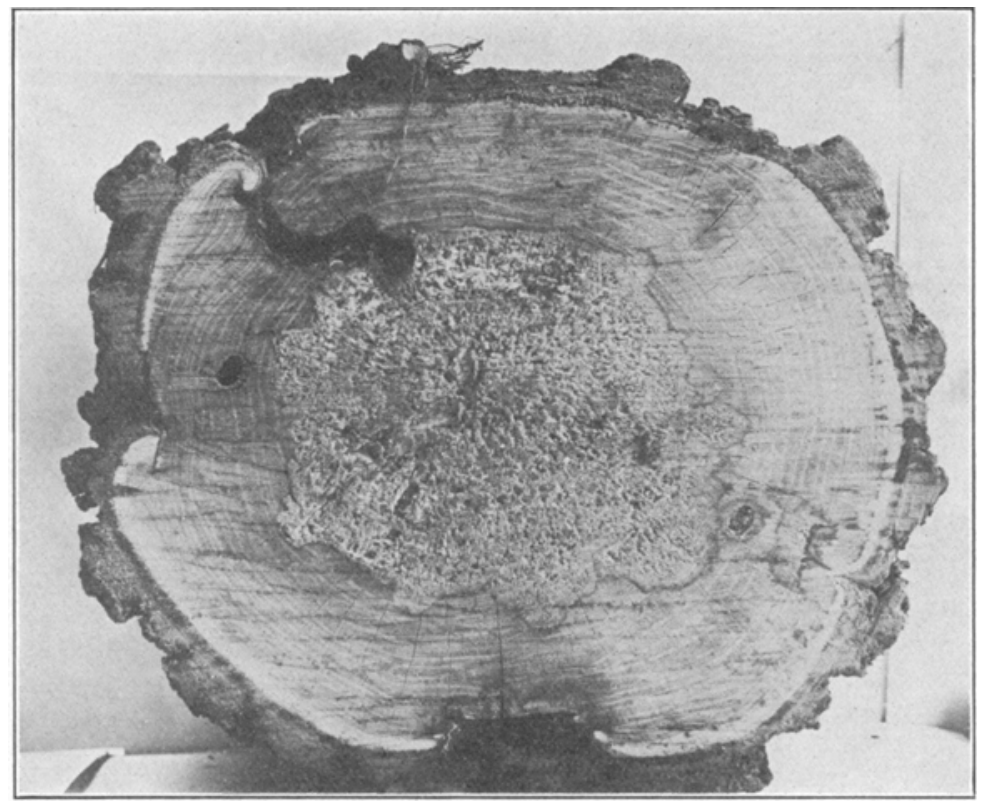

FIG. 3. Cross-sectional view of section VI, showing very clearly the appearance of the rot in the heartwood of the black locust.

being tested, a condition, however, which should favor the inferences drawn from the results of the tests.

TABLE 3. Tests of Blocks from Section VI

\begin{tabular}{|c|c|c|c|c|c|c|c|}
\hline \multirow{2}{*}{ Block } & \multirow{2}{*}{ Size (Inches) } & \multicolumn{3}{|c|}{ Crushing Strength } & \multicolumn{3}{|c|}{ Crushing Strength per Sq. In. } \\
\hline & & Ist Fail & 2d Fail & 3d Fail & $\mathbf{I}$ & 2 & 3 \\
\hline $\begin{array}{l}\mathrm{I} x \ldots \ldots \\
2 x \ldots \ldots\end{array}$ & $\begin{array}{l}\mathrm{I} .6 \mathrm{I} \times \mathrm{I} .84 \\
\mathrm{I} .6 \times \mathrm{I} .33\end{array}$ & $\begin{array}{l}23,000 \\
14,500\end{array}$ & $\begin{array}{l}23,500 \\
15,500\end{array}$ & $\begin{array}{l}24,500 \\
16,500\end{array}$ & $\begin{array}{l}7,770 \\
6,813\end{array}$ & $\begin{array}{l}7,939 \\
7,277\end{array}$ & $\begin{array}{l}8,256 \\
7,746\end{array}$ \\
\hline
\end{tabular}

[The standard of 1o,888 lbs. per sq. in. of perfectly sound locust is taken from Newlin and Wilson (I91 7, p. 40).]

It will be observed that the blocks from section VI had been materially weakened by from 2,000 to 3,000 pounds through the advance of mycelium. The blocks from section IV had been weakened in some cases by half. As is evident at once from a glance through the tables, blocks I, 2, and 3 all average about the same per square inch when compressed parallel to the 
TABLE 4. Apparently Sound Wood Taken from Section IV

Blocks $I, 2$, and 3 , nearest the decayed area; blocks $3,4,5$ and 6 , farthest away from the diseased area.

\begin{tabular}{|c|c|c|c|c|c|c|c|}
\hline \multirow{2}{*}{ Block } & \multirow{2}{*}{ Size (Inches) } & \multicolumn{3}{|c|}{ Crushing Strength } & \multicolumn{3}{|c|}{ Crushing Strength per Sq. In. } \\
\hline & & Ist Fail & 2d Fail & 3d Fail & I & 2 & 3 \\
\hline $\begin{array}{l}1 \ldots \ldots \\
2 \ldots \ldots \\
3 \ldots \ldots \\
4 \ldots \ldots \\
5 \ldots \ldots \\
6 \ldots \ldots\end{array}$ & $\begin{array}{l}1.87 \times 1.87 \\
1.85 \times 1.87 \\
1.80 \times 1.80 \\
1.82 \times 1.79 \\
1.79 \times 1.75 \\
1.83 \times 1.80\end{array}$ & $\begin{array}{l}20,000 \\
19,000 \\
22,000 \\
26,500 \\
29,000 \\
26,000\end{array}$ & $\begin{array}{l}20,000 \\
20,000 \\
22,000 \\
27,000 \\
29,000 \\
26,000\end{array}$ & $\begin{array}{l}20,500 \\
20,000 \\
22,000 \\
27,000 \\
29,000 \\
26,000\end{array}$ & $\begin{array}{l}5,7 \text { I } 4 \\
5,277 \\
6,790 \\
8,134 \\
9,257 \\
7,893\end{array}$ & $\begin{array}{l}\mathbf{5}, 857 \\
5,555 \\
6,790 \\
8,250 \\
9,257 \\
7,893\end{array}$ & $\begin{array}{l}\mathbf{5 , 8 5 7} \\
\mathbf{5 , 5 5 5} \\
6,790 \\
8,250 \\
9,257 \\
7,893\end{array}$ \\
\hline
\end{tabular}

grain, whereas blocks 4,5 , and 6 , which were taken from a greater distance away from the rot, run much higher but still do not approach normal except in the case of block 5, which shows the highest strength per square inch but no resiliency of the wood. In blocks taken from section VI, there is a distinct difference between the first failure and the third failure of about 500-90o pounds, but it should be compared with the test of section IV, in which the failure is final in most cases for a certain load. When the blocks give, they give all at once, which is contrary to what we expect from normal locust wood. It was also noticed in the testing of all the blocks that up to about the final $2 / 3$ pounds per square inch the blocks behaved quite normally, but after heavier weights were applied, the wood reacted in general like one of the softer deciduous woods.

\section{Discussion and Summary}

Several points brought out in this study may prove of far-reaching significance. As already indicated in the remarks about the blackishbrown zone (page 50I), certain ideas concerning the occlusions in the elements of this zone must be revised. In this case, at least, these occlusions can play no part as a protection against invading mycelium, as was suggested by Lindroth (1904) and others. Nor can we generalize, as did Rhoads (1917), that "the brown substance... is indicative of the first stage in the decomposition of the wood"; for the beginnings of the weakening of infected wood, as shown by the tests, are already initiated outside the black zone for a considerable distance, and are probably much more advanced than a microscopic observation alone shows.

"Advance rot" has in recent years been given considerable attention, and during the world war the price paid in human lives as a result of weak spots in aeroplane timber instigated special research along this line by the national government. Unfortunately the results of these studies are not yet available in the literature. Boyce (1920, p. 15) found in the dry rot of incense cedar, where the decayed areas alternate with apparently sound wood, that "hyphae were commonly present in the apparently sound wood 
surrounding young pockets to a distance of $4 \mathrm{~mm}$., and sparingly to $8 \mathrm{~mm}$. in a horizontal direction," while he found scattered mycelium vertically beyond the last decay pocket to a distance of $7.8 \mathrm{~cm}$. Meinecke (I914) found the advance rot of Echinodontium tinctorum on Abies concolor to extend vertically from 2 to 6 feet beyond the typical rot. Weir and Hubert (1918), working with the same fungus on Tsuga heterophylla, report advance rot recognizable at from $I$ to 5 feet. In these cases a trained observer can usually recognize the advance made by the fungus by slight irregularities in color by streaks. Münch (I9IO) working with a sap-rot, Stereum purpureum on poplar, perceived that the advancing hyphae preceded the zone of browning to some extent.

Hartig (1894), speaking of cut timber, suggested long ago that mycelium might be expected in the apparently sound regions of such wood. In the lilac, Von Schrenk (1914) emphasizes the sharpness of the line between "sound" and completely destroyed wood, and all observers know that this is a frequent condition on gross examination. Fomes igniarius on poplar, occurring along tamarack swamps in Michigan, shows this contrast most markedly. In other heart-rots like that produced by Polyporus hispidus and Fomes fraxinophilus on ash, dried-out logs often show a rather indistinct demarcation. But although no generalization can be attempted from the one case studied by us, it would seem that others of the heart-rots found in the hardwoods might be expected to show advance rot, and perhaps to an unsuspected linear extent. The economic importance of this point grows in proportion to the scarcity of sound trees, and the temptation to inspectors of timber to pass slightly decayed stuff is only too well known by our lumber-using manufacturers. If the weakening of the apparently sound wood surrounding a narrow core of rot in a large log of valuable timber were only half what our test figures show, it might still be of serious significance when used for certain structures.

A very interesting academic question remains to be solved in connection with the majority-or at least many-of the heart-rots. What becomes of the mycelium in the rotten core inside the black zone? For years, the senior writer has had his class in forest pathology attempt to locate mycelium in sections of recently cut trees with various heart rots, but in most cases the observations ended negatively, even with most persistent efforts. Mycelium seems to be lacking in most cases in the advanced stage of the rot, or remains only in pockets or cracks as "nests" or "punk," while the rotten tissues seem to be free from it. Hypha-holes and corrosion of the elements in various degrees are easily observed. As noted in detail, this was the situation in the locust tree studied. This, of course, is not true of timber attacked by fungi after cutting, nor apparently of sap-rots, working from without inwards. But even here our data are not very complete. Brown (I9I5), however, speaking of rot caused by Hymenochaete, says that "in an advanced stage of decay only the openings are left as the hyphae 
disappear." Boyce (I920) notes that in the incense-cedar rot "hyphae were very rare in the pockets of badly decayed wood," although nests of mycelium occurred in places. He also notes that hyphae must have been present earlier because of the hypha-holes in the cell walls. In the slightly decayed wood of the incense cedar hyphae occur abundantly, although Boyce states elsewhere that "the line of demarcation between sound and decayed wood is very sharp." We have here, then, a situation somewhat different from our case in that hyphae occur back of the line of demarcation, although they disappear later. Von Schrenk and Spaulding (1909) seemed to have little difficulty in finding mycelium of Fomes igniarius "in the completely decayed" wood, where, according to these authors, "the mycelium of the fungus is abundant in the large vessels and medullary rays." The hardwood host or hosts which were studied are not mentioned, and it may be presumed-albeit at some risk-that the matter is a variable and that the most frequent condition is not such as they describe. There is, furthermore, no doubt that small masses of hyphae do accumulate in nests or broken-down cavities and there persist, perhaps because of their bulk. The question remains, what happens to the other portions? How do the isolated hyphae, responsible for innumerable holes in cell walls, disappear? Having exhausted the food, they may die and disintegrate. We may say they are resorbed. But this leaves : he matter vague, especially as applied to the portions near the line of demarcation between the rot and the apparently sound wood where one would expect dead hyphae to remain visible. The idea of dissolving themselves (resorption) by the ferments of their own making seems unlikely. One other explanation easily comes to mind, viz., that bacteria follow the course of the rot, gaining entrance by the same path as the wound parasite, and destroying the mycelium as soon as the latter has lost its vigor. At first thought this explanation seems plausible. So far, however, no bacteria of wood-destroying ability seem to have been isolated. Schmitz (I9I9), on the other hand, found strong indications that certain heart-rotting fungi will destroy more wood in the presence of some common and widely distributed bacteria than when these flugi function by themselves. Meanwhile the rotten core seems to be disintegrating still further through the action of some agent. May not the mycelium while still present secrete enough enzyms, which persist actively for a considerable time, and which are responsible for the continued disintegration going on in the rotten core? This whole question still has a strongly unsolved quality and needs further attack.

Although the laboratory and field work was done entirely by $\mathrm{Mr}$. Kerber, the points were worked out by constant coöperation. The authors are under much obligation to Prof. Filibert Roth for the use of the testing machine and for assistance in making the tests; and to Dr. W. W. Tupper for valuable advice and assistance in the study and staining of the locust wood.

Cryptogamic Laboratory, UNIVERSITY OF MICHIGAN 


\section{LITERATURE CITED}

Boyce, J. S. 1920. The dry-rot of incense cedar. U. S. Dept. Agr. Bur. Plant Ind. Bull. 87I.

Brown, H. P. IgI5. A timber-rot accompanying Hymenochaete rubiginosa. (Schrad.) Lév. Mycologia 7: r-20.

Hartig, R. I 894. The diseases of trees (Eng. transl.).

Lindroth, J. I904. Beiträge zur Kenntniss der Zersetzungserscheinungen des Birkenholzes. Naturw. Zeitschr. Forst- u. Landw. 2: 393-406.

Meinicke, E. P. 1914. Forest tree diseases common in California and Nevada. A manual for field use. U. S. Dept. Agr. For. Serv.

Münch, E. rgro. Versuche über Baumkrankheiten. Naturw. Zeitschr. Forst- u. Landw. 8: 389-408; 425-447. Über krankhafte Kernbildung. Ibid. 8: 533-547; 553-569.

Newlin, J. A., and Wilson, T. R. C. 1917. Mechanical properties of woods grown in the United States. U. S. Dept. Agr. Contr. For. Serv. Bull. 556.

Rhoads, A. S. 1917. The black zones formed by wood-destroying fungi. N. Y. State Coll. Forest. Techn. Publ. 8.

Schmitz, H. I919. Studies in the physiology of the fungi VI. The relation of bacteria to cellulose fermentation induced by fungi, with special reference to the decay of wood. Ann. Mo. Bot. Gard. 6: 93-136.

Von Schrenk, H. 1914. A trunk disease of the lilac. Ann. Mo. Bot. Gard. I: 253-260. and Spaulding, P. 1909. Diseases of deciduous forest trees. U. S. Dept. Agr. Bur. Plant Ind. Bull. 149.

Weir, J. R., and Hubert, E. E. 1918. A study of heart-rot in western hemlock. U. S. Dept. Agr. Bur. Plant Ind. Bull. 722. 